\title{
Podcast "Sandiwara Sastra" as a Media for the Development of Literary Works
}

\author{
Nanda Meg Ryan Puspitasari Supriyono ${ }^{1}$; Nurul Fadilah ${ }^{2}$; Alvina Nuraeni ${ }^{3}$; \\ Chica Friskilla ${ }^{4}$; Moses Glorino Rumambo Pandin ${ }^{5}$ \\ 1,2,3,4,5 English Department, Faculty of Humanities, Universitas Airlangga \\ ${ }^{1}$ nanda.meg.ryan-2020@ fib.unair.ac.id; ${ }^{5}$ moses.glorino@ fib.unair.ac.id
}

\author{
*Corresponding Author \\ Moses Glorino Rumambo Pandin \\ Faculty of Humanities, Universitas Airlangga \\ Jl. Dharmawangsa Dalam Selatan, Kampus B, Surabaya 60286 \\ moses.glorino@fib.unair.ac.id
}

\begin{abstract}
Background: The development of technology has encouraged a more developed civilization. However, one of the impacts is causing low students' interest in literature. In this case, optimizing digital media is one way of developing literary works. Based on this problem, the researchers set the question: What is the role of the podcast "Sandiwara Sastra" as an alternative to developing Indonesian literary works?. Purpose: This study aims to increase students' interest in literature and make the delivery of literary works flexible. Method: This study uses a qualitative descriptive method. The qualitative method uses an online survey that focuses on respondents' opinions with 44 college students. The sample criteria used are college students aged 19-25 years and have listened to podcasts. Then, the researcher used the interview method using ten interviewees to strengthen the results of the online survey analysis. Results: The role of the "Sandiwara Sastra" podcast can influence students' interpretations to study literature more flexibly and increase their interest in literature. Recommendation: This study is expected to increase college students' understanding and interest in literature through digital podcast media. Limitation: The limited variety of respondents who only cover college students, so generalization needs to be improved.
\end{abstract}

Keywords: Literature, Podcast, Students, Digital, Development

\section{INTRODUCTION}

Since the emergence of the term modernization, humans have been at the gate of a new age. The development of technology itself has encouraged a more developed and advanced civilization. However, all developments do not necessarily have a positive impact. One of the impacts is the decline in public interest in literature. The results of a survey conducted by the Center for Educational and Cultural Policy Research in 2019, which revealed that the average number of the National Alibaca Index was in the category of low literacy activity, from a scale of 0 - 100 at 37.32, can be evidence that literature has decreased in public. Literature can reflect reality, which has an extraordinary role and influence on life. The position of literature is significant in the context of cultural progress and the formation of national character. In this case, the solution of this problem is optimizing digital media as a medium 
for developing literary works. Because of that, researchers are interested in looking for ideas about literary development in this millennial era. One of the innovations that researchers can make is using podcasts to transfer literary works into audio form.

According to Brown, A., \& Green, T. D (2007) in Zellatifanny's research (2020), Podcast is audio or video files uploaded on the web to be accessed by everyone, whether subscribed or not and can be listened to or watched using a computer and portable digital media player. Geoghegan \& Klass (2007) stated in Kencana (2020) that podcasting is an exciting development of media technology because anyone can get involved, express themselves, exchange ideas, or promote their products. Not only appears in social media and websites, but the media chosen to express ideas and create literary works can be accessed in the form of podcasts with Spotify application. Besides that, based on research conducted by Hutabarat P.M, one of the benefits of podcasts is acting as a medium of information, entertainment and an educational medium that students can use anytime, anywhere. Podcasts can be said to be one of the media currently a trend in society. One type of podcast is considered effective in developing and spreading literature to the broader community. This podcast is accessible in @ budayakita, which contains Sandiwara Sastra (Audio Theatrical Literature). This program results from collaborating with the Ministry of Education and Culture, Titimangsa Foundation, and KawanKawan Media to produce podcasts adapted from Indonesian literary works.

In Fauziah's research (2020), Farid revealed that the Sandiwara Sastra podcast is a media that contains various novels, short stories, and other literary works packaged in audio form. This podcast acts as a work of art and innovation in creative production. It launched as a vehicle for transferring from text to audio so that it would be able to arouse the Indonesian people's interest in Indonesian literature. Furthermore, this podcast involves Indonesian actors and actresses as voice actors and narrators, such as Kevin Ardilova, Chelsea Islan, Chicco Jericho, Christine Hakim, Najwa Shihab, and other figures. The involvement of these public figures can attract the public's attention in enjoying the Literary Drama Program on the @ budayakita podcast. It can also provide entertainment with beneficial values for society to help mental health in pandemic situations.

According to Kastanya (2020), the students only found literature's form in print media in ancient times, such as in newspapers, magazines, and books. Through various media, the development of literature started disseminated. However, along with the times, technology is also growing. Various Indonesian literary works can be found through electronic and online media, usually through increasingly sophisticated radio, television, and the internet. In this case, the use of digital media is a powerful hegemony in developing literature in society (Sulaiman, 2020:164). Digital literature research conducted by Yusanta and Wati (2020) reveals that the emergence of cyber literature or electronic literature as a response to the development of the digital world is considered capable of attracting interest and inspiring young writers to be creative. Nurhiddayah and Setiawan (2019) also stated that students could positively receive literary works through electronic media. Because electronic media can trigger new dynamics and potential from the authors, the splendor of literary works can increase due to the existence of electronic media platforms. The emergence of cyber literature can be an innovation in literary production that has been dependent on print publishing. Based on the problem and innovation opportunities presented earlier, the researcher would like to set the following research question: What is the role of the "Sandiwara Sastra" podcast as an alternative to developing Indonesian literary works? Thus, the researcher explores how 
the role of the podcast "Sandiwara Sastra" so that it can be an alternative in developing literary works.

\section{METHOD}

In this study, the researchers used a qualitative approach. First, researchers identify the problem or determine the research object to find materials/data that will allow them to discover the novelty or advantages from their study with previous research. Then, the researchers collected data by selecting data that could be analyzed or interpreted to produce new ideas or theories.

Research data collection techniques using interview and survey methods. The interview was conducted to complete, find out and obtain accurate data sources. The researchers interviewed 10 interviewees, with the majority from Universitas Airlangga. Interviewees in the interview method continue to develop (snowball) purposively until the data found are considered satisfactory or reach data saturation. Next, the survey method was carried out through an online questionnaire. For the sample, we took 44 students as respondents with an age range of 19-25 years and had listened to podcasts. The population of respondents includes all college students in East Java. However, most of the respondents came from Airlangga University college students. The list of questions in the questionnaire consists of 9 questions, of which 5 are closed questions (answers have been provided) and 4 open questions (answers from respondents).

Researchers use the theory of Sugiyono (2015) to check the validity of qualitative research data that contains transferability, dependency, and confirmability tests. Data testing (internal validity) uses triangulation to find similarities between what the researcher reports and what happened to the object under study. The researchers also tested the data with a transferability test to achieve precise research results (context and research focus). Furthermore, the researchers also conducted a data dependence test (reliability) which means the data can be reliable if it has carried out a series of actual processes (data collection, checking data validity, data analysis, and conclusion). Lastly, researchers tested the data through confirmability testing, including checking the quality and research results whether they came from data collection.

Data analysis in this study used a qualitative descriptive analysis technique which includes reducing data (data reduction), presenting data (data display), and drawing conclusion (conclusion/verification). First, the collected data are identified for similarities and grouped to facilitate prioritization or ranking at the next stage. The prioritized data are collected to draw the conclusion. Then, the results of data presentation are concluded to produce a grounded theory. Grounded theory is a theory found inductively, based on data found in the field, and then tested through continuous data collection. 


\section{Study Design}

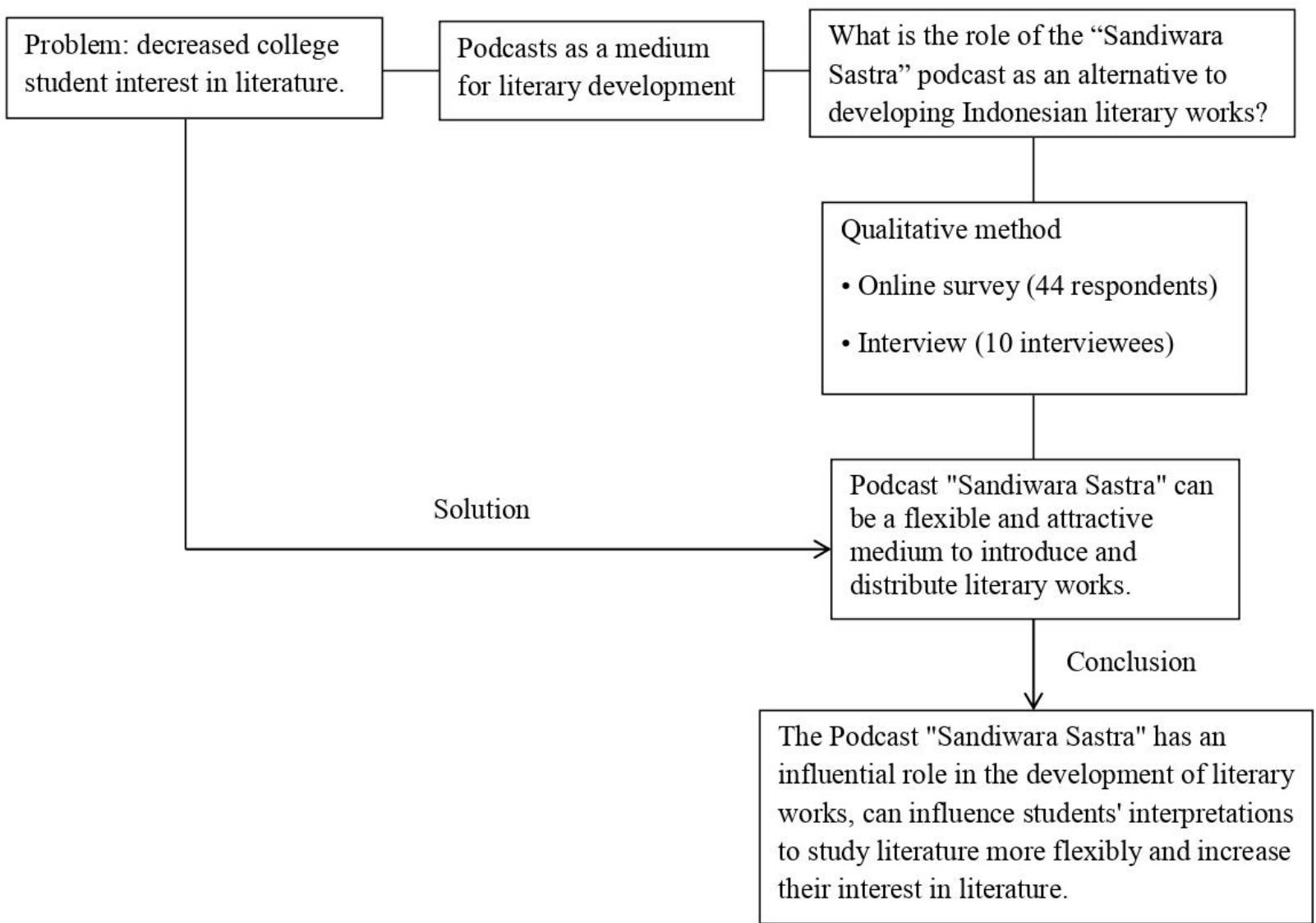

Diagram 1. Study Design

\section{RESULTS}

The results of data classification based on respondents' opinions are listed below.

Table 1. Closed Question

\begin{tabular}{|c|l|c|c|c|c|}
\hline No. & \multicolumn{1}{|c|}{ STATEMENT } & $\begin{array}{c}\text { NUMBER OF } \\
\text { RESPONDENT } \\
\text { (YES) }\end{array}$ & YES & $\begin{array}{c}\text { NUMBER OF } \\
\text { RESPONDENT } \\
\text { (NO) }\end{array}$ & NO \\
\hline 1 & $\begin{array}{l}\text { Listening to podcast for } \\
\text { entertainment }\end{array}$ & 41 & $93,2 \%$ & 3 & $6,8 \%$ \\
\hline
\end{tabular}




\begin{tabular}{|c|l|c|c|c|c|}
\hline 2 & $\begin{array}{l}\text { Decreased public interest } \\
\text { in literature }\end{array}$ & 38 & $86,4 \%$ & 6 & $13,6 \%$ \\
\hline 3 & $\begin{array}{l}\text { Interest in listening to } \\
\text { literature through podcasts }\end{array}$ & 39 & $88,6 \%$ & 5 & $11,4 \%$ \\
\hline 4 & $\begin{array}{l}\text { Knowing the podcast } \\
\text { "Sandiwara Sastra" which } \\
\text { is a vehicle for Indonesian } \\
\text { literary works into audio } \\
\text { medium }\end{array}$ & $20,5 \%$ & 35 & $79,5 \%$ \\
\hline
\end{tabular}

Based on the analysis in table 1 , about $93.2 \%$ of college students stated that they had listened to podcasts as a means of entertainment, and only $6.8 \%$ of students indicated that they had never listened to podcasts. It shows that podcasts are no longer a foreign medium for society, especially young people and students. Furthermore, the level of student interest in listening to digital media podcasts is much greater, which is around $88.6 \%$, compared to students who are not interested in podcasts, which are $11.4 \%$. In this case, we use a podcast called "Sandiwara Sastra" as a medium to introduce literature to students. Then, accounting for $86.4 \%$ of students agree that public interest in literature in the digital era is currently decreasing, and $13.6 \%$ of students express disagreement about the statement of declining public interest in literature in the digital age. This case has been proven that students are aware of the decline in interest in literature in this era. In addition, around $79.5 \%$ of students stated that they were not familiar with this podcast, and only $20.5 \%$ of students were familiar with the podcast "Sandiwara Sastra." The lack of knowledge about the "Sandiwara Sastra" podcast, which transfers literary works into audio medium, indicates that this podcast's delivery of literary works has not yet reached the wider community, including college students.

Table 2. Open Question

\begin{tabular}{|c|c|c|c|c|}
\hline No. & Observed aspects & Respondents Response & $\begin{array}{l}\text { Number of } \\
\text { Respondents }\end{array}$ & Percentage \\
\hline \multirow[t]{2}{*}{1.} & \multirow{2}{*}{$\begin{array}{l}\text { The Role of } \\
\text { Literature in } \\
\text { People's Lives in } \\
\text { the Digital Age }\end{array}$} & $\begin{array}{l}\text { Way of looking and } \\
\text { thinking }\end{array}$ & 14 & $38,88 \%$ \\
\hline & & Adding insight & 12 & $33,33 \%$ \\
\hline
\end{tabular}




\begin{tabular}{|c|c|c|c|c|}
\hline & & Communication & 10 & $27,77 \%$ \\
\hline \multirow[t]{3}{*}{2.} & \multirow{3}{*}{$\begin{array}{l}\text { Factors of Low } \\
\text { Public Interest in } \\
\text { Reading }\end{array}$} & $\begin{array}{l}\text { The influence of digital } \\
\text { media }\end{array}$ & 14 & $40 \%$ \\
\hline & & $\begin{array}{l}\text { Lack of application of } \\
\text { literacy culture since } \\
\text { early age }\end{array}$ & 13 & $37,14 \%$ \\
\hline & & $\begin{array}{l}\text { Less interesting reading } \\
\text { facilities and media }\end{array}$ & 8 & $22,85 \%$ \\
\hline \multirow[t]{3}{*}{3.} & \multirow{3}{*}{$\begin{array}{l}\text { Experiences and } \\
\text { Benefits After } \\
\text { Listening to the } \\
\text { "Sandiwara Sastra" } \\
\text { Podcast }\end{array}$} & $\begin{array}{l}\text { Unfamiliar about } \\
\text { "Sandiwara Sastra" } \\
\text { podcast }\end{array}$ & 39 & $88,63 \%$ \\
\hline & & Find new perspectives & 3 & $6,81 \%$ \\
\hline & & $\begin{array}{l}\text { Increasing interest in } \\
\text { literature }\end{array}$ & 2 & $4,54 \%$ \\
\hline \multirow[t]{3}{*}{4.} & \multirow[t]{3}{*}{$\begin{array}{l}\text { The Role of } \\
\text { Literary Podcasts in } \\
\text { the Digital Age }\end{array}$} & Innovation in literature & 13 & $43,33 \%$ \\
\hline & & $\begin{array}{l}\text { Increasing public } \\
\text { knowledge about } \\
\text { literature }\end{array}$ & 9 & $30 \%$ \\
\hline & & Alternative learning & 8 & $26,66 \%$ \\
\hline
\end{tabular}

Based on table 2, section 1, which has been analyzed, proclaims that literature has an essential role in the digital era. From $100 \%$, only $2.27 \%$ of students indicated that literature has no value in the digital age. The remaining $97.72 \%$ of students who started their agreement had several different opinions regarding the role of literature in the digital era. About $38.88 \%$ of students think that literature in this era can influence and change the 
public's perspective on literature and human life in this digital age. Then, as many as $33.33 \%$ of college students considered literature to add insight and develop human thought poured into a literary work. It can also develop ideas and creativity in the digital era. The final opinion with a percentage of $27.77 \%$ of students stated the role of literature in communication and exchanging ideas in people's lives in the digital era. They assume that literature can be a medium and an effective means to channel thoughts and messages for the community.

Furthermore, the analysis in table 2, section 2, explains the low awareness of reading interest in Indonesia. UNESCO stated that Indonesia is second from the bottom in world literacy. All respondents agreed with the statement and gave their opinion about the factors causing the low interest in reading in the community. The existence of the digital life that is practical and fast-paced is the cause most expressed by our respondents. As many as $40 \%$ of students think that their lack of interest in books or other literary works is caused by the high public interest in a practical world. Today's society, especially college students, prefers to use digital media to support their daily lives because the system is more valuable than books. The second factor in the decline in people's interest in reading is the lack of habituation to reading from an early age. Around $37.14 \%$ of students think that the lack of reading habits from an early age and education from parents is a factor in the low interest in reading in Indonesian society. Parents certainly impact the lack of awareness of reading interest in the future, including in the present. About $22.85 \%$ of students saw the last factor from the external aspect. This outer aspect includes the facilities and appearance of the current reading media. The facilities and appearance that are less attractive from some reading media cause people to be less interested in reading books and literary works. Therefore, respondents suggested an innovation in books and literary works to attract more people reading interest in the digital era.

Table 2, section 3, shows the percentage of students who know about the "Sandiwara Sastra" podcast. It is calculated that $88.63 \%$ of students have never listened to the podcast, so they do not have the experience and benefits after listening to this podcast. Then, only $11.36 \%$ of students have listened to this podcast. About $4.54 \%$ of students stated that they are more interested in literary works, and $6.81 \%$ of students said that the benefits of the podcast could add to their insight into literature that comes from experts. The podcast opens their new views and thoughts about culture and literature.

Based on the analysis of table 2, section 4, as many as $97.72 \%$ of $100 \%$ respondents stated that the role of literary podcasts is essential to developing literature in the digital era. From $97.72 \%$ of students, we found that $43.33 \%$ of students explained the role of literary podcasts as innovations in the world of literature in the digital era. The invention in question is a new form of literature, namely podcasts. This literary podcast can indeed change people's mindset about the monotonous appearance of literature. With the literary podcast media, a new view of literature will be created that is packaged more attractively and adapts to the development of the digital era. Another $30 \%$ of students stated that literary podcasts play a role in increasing public knowledge of literature. They explained that the flexibility and ease of access to podcasts are the fine points in the medium for delivering literary works. Many 
people can listen to podcasts while doing other activities so that messages and information in literary works that are topics in podcasts still be conveyed. This fact certainly expands and develops literature in the digital era. Furthermore, $26.66 \%$ of respondents said that literary podcasts are an alternative for learning literary works. The number of people who are still not literate requires a solution to improve literature learning, namely by using podcast media to discuss topics about literature.

\section{Interview Result}

In addition, researchers also used the interview method to strengthen the researchers' survey data. Based on the interviews with ten students, we found that most of the interviewees said that the podcast "Sandiwara Sastra" greatly influenced public interest in studying literature. In other words, this podcast can be an innovation in media dissemination which is the introduction of literature in a new form to be accessed by many people, especially young people in the current digital era. Most interviewees also said that this podcast could be a learning alternative to study literature flexibly and interestingly. In addition, other interviewees revealed that this podcast could increase people's knowledge about literature by introducing and interpreting various literary works. Therefore, we conclude that the "Sandiwara Sastra" podcast has an influential role in developing literature, which can become an innovation, alternative learning and increase knowledge in literature.

Regarding the experience and perceived benefits of listening to the "Sandiwara Sastra" podcast, most of the information admitted that they are not familiar with this podcast, so they do not have experience using this media. However, some other interviewees felt that they got new views and experiences studying literature. The experience is felt because of the literary learning model with an attractive and flexible form. In addition, this podcast can also add new perspectives, which can increase vocabulary and increase knowledge about literary elements. Several other interviewees said that this media effectively increased their interest in literature because they are more interested in studying literature through practical and flexible media. 


\section{The following is the results of coding networking}

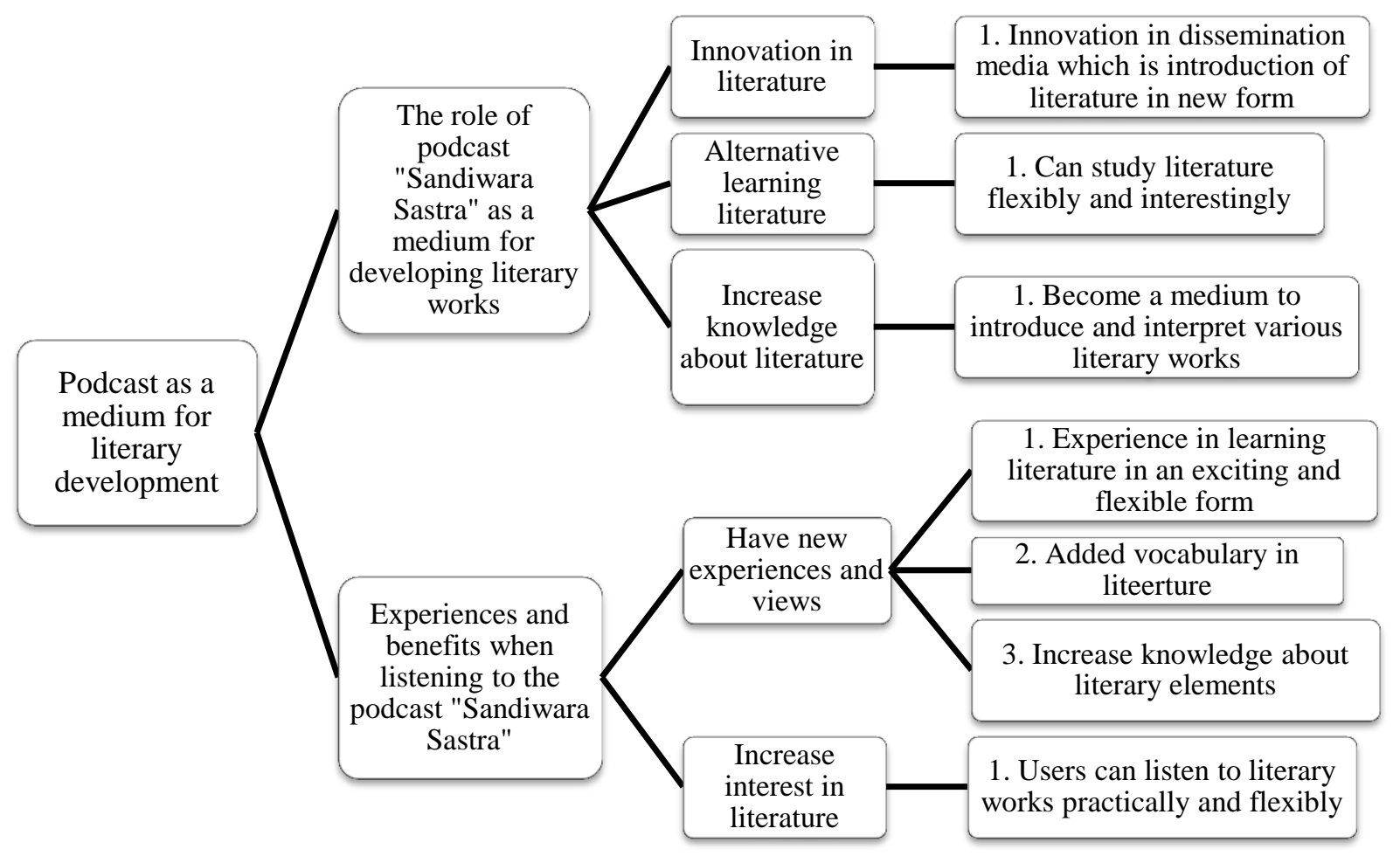

Diagram 2. Coding Networking

\section{Validity and Reliability Test}

The researcher's data has been analyzed through Sugiyono's (2015) theory, namely the credibility, transferability, dependability, and confirmability test to check the validity of the data in qualitative research. Credibility testing is carried out to test the trustworthiness of the resulting data. This test is executed by searching for similarities between the data and the theory of previous researchers. This study uses triangulation of interview data, surveys, and journals to find similarities in the data results. At this stage, researchers have found accurate data where podcasts have a high enough preference so that it is possible to be used as an alternative medium for literary development.

Furthermore, the researcher tested the data using dependability testing, where the data could be reliable if it had carried out a series of fundamental research processes. The data that the researcher obtained has met a series of processes before finally drawing a conclusion that says that podcasts are a viable digital medium that can be used as an alternative medium to developing Indonesian literature. Then, the data is tested by confirmability testing, namely checking the quality and certainty of the research results, whether it comes from data collection. Researchers consistently report the research data results and then examine them as 
carefully as possible so that the researchers' findings do not get out of the research context. Finally, the data is tested through transferability testing, where the reader can understand the research results (context and research focus). The researcher asked several volunteers to read the results of our research and found that they understood the context of the study, namely the role of podcasts in building and increasing students' motivation and interest in Indonesian literary works.

\section{DISCUSSION}

\section{The Role of Digital Media Podcast "Sandiwara Sastra" as an Alternative for the Development of Indonesian Literary Works}

In the era of modernization that involves technology, humans enter the gates of a new age with an increasingly advanced civilization. However, the rapid flow of modernization is also accompanied by negative impacts such as the fading of the nation's culture, one of which is Indonesian literature. The Center for Education and Culture Policy Studies conducted a literacy activity survey in 2019, revealing that the average National Alibaca Index was in the low literacy activity category, only 37.32 on a scale of $0-100$. The score consists of fourdimensional indices, including the Proficiency Dimension Index 75.92; Access Dimension Index 23.09; Alternative Dimension Index of 40.49; and the Cultural Dimension Index of 28.50. The above conditions illustrate the need for strenuous efforts so that public interest in reading, especially students, in Indonesian literary works can be further improved. To overcome the problem of the literature existence that is starting to fade, technological advances and innovation can be a solution by developing media that are more adaptive to the interests of today's society. One of these development media is a podcast that presents a new face in its presentation in audio form.

According to Brown, A., \& Green, T. D (2007) in Zellatifanny's research (2020), Podcasts are audio or video files uploaded on the web to be accessed by everyone, whether subscribed or not and can be listened to or watched using a computer and portable digital media player. Geoghegan \& Klass (2007) stated in Kencana (2020) that podcasting is an exciting development of media technology because anyone can get involved, express themselves, exchange ideas, or promote their products. A podcast is an audio-based communication channel introduced in 2006 in the United States. Based on Statista (2001), only 22\% of the adult population in the United States knew about podcasting at the beginning of its emergence. Along with the year's development, namely in 2020, this number has increased to reach $75 \%$. The popularity of podcasting reached 88 million listeners in 2019. It is estimated that this number will continue to increase to 160 million listeners by 2023 , with an estimated increase of 20 million listeners every year. The existence of podcasts is growing worldwide, one of which is Indonesia. Since 2018, its development has been considered relatively rapid, marked by significant growth of enthusiasts. As of May 2020, it is known that podcast listeners in Indonesia continue to grow and have now reached the highest number of listeners in Southeast Asia, namely as many as $20 \%$ of users listen to podcasts every month. This 
increase in listeners led to the emergence of several streaming applications such as PodMe, Noice, Spotify, and others in 2019.

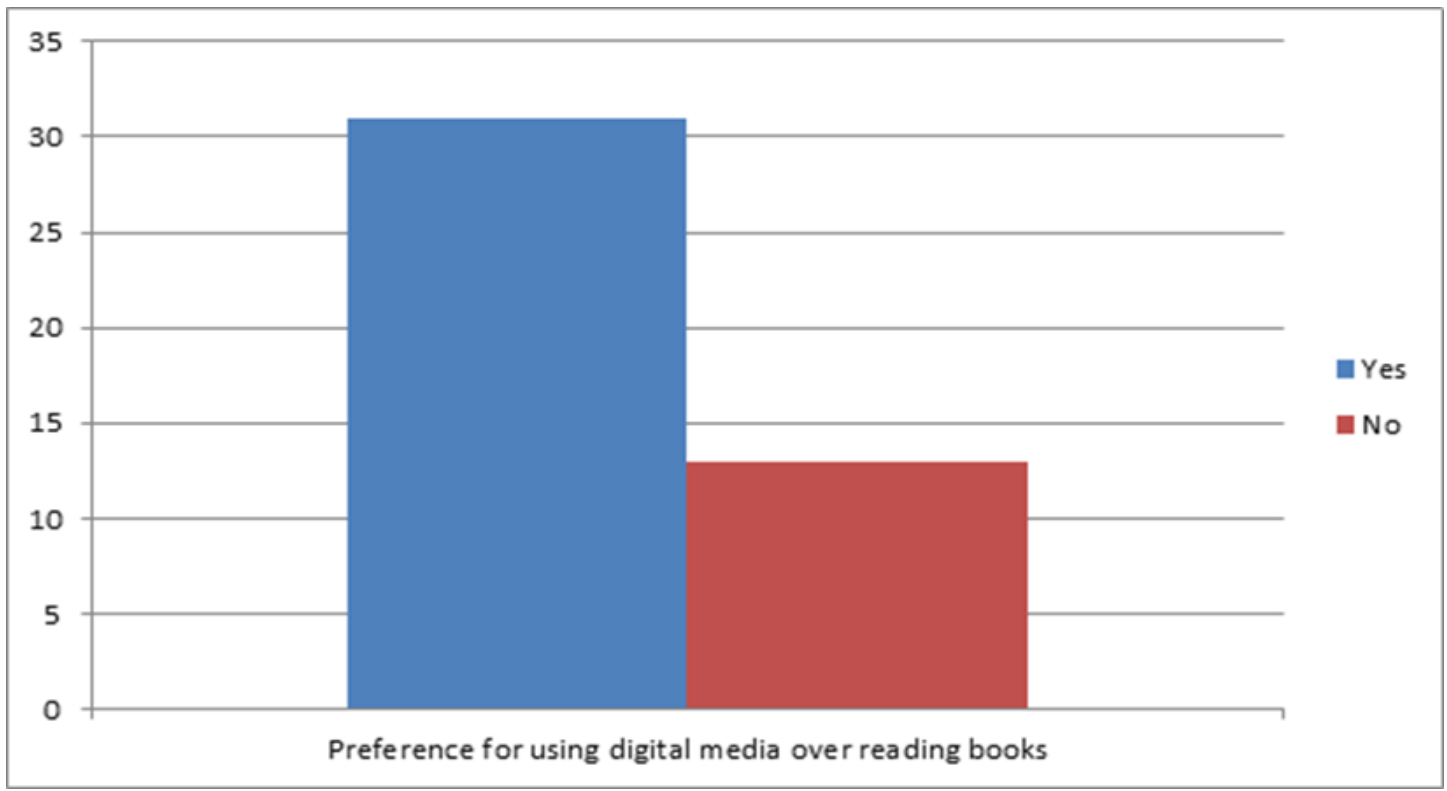

Diagram 3. Podcast Media Usage Preference

Podcasts are considered to have a role in giving a new face to the development of Indonesian literary works. The level of interest is relevant and follows the research results that we present in the form of a diagram, revealing that as many as 31 of 44 students often use podcasts as a medium of entertainment. In this case, students prefer digital media such as podcasts, audiobooks, or videos as literacy media rather than reading books. It shows that as the current generation, students follow the development of existing technology and utilize technology by utilizing digital media for entertainment and broadening their horizons. Meanwhile, the use of podcasts as a digital media preference also revealed a relatively high percentage, namely $72.7 \%$.

The presence of "Sandiwara Sastra" which is a transfer of literary vehicles into audio form, can be a solution to increase public literacy interest, especially the younger generation towards Indonesian literary works by involving leading public figures. The Sandiwara Sastra program adapted 10 works of Indonesian literature, namely Ronggeng Dukuh Paruk by Ahmad Tohari; the novel Helen and Sukanta by Pidi Baiq; the short story Independence by Putu Wijaya; the short story Waiting for Herman by Dee Lestari; the short story Berita from Kebayoran by Pramoedya Ananta Toer; the novel Lalita by Ayu Utami; short story A Thousand Fireflies in Manhattan by Umar Kayam; the short story Persekot by Eka Kurniawan; the novel Layar Terkembang by Sutan Takdir Alisjahbana, and the novel Orang Oetimu by Felix K. Nesi. Of course, by presenting various literary works with various prominent visual figures, students feel that apart from giving new entertainment, the presence of this podcast also provides various knowledge related to literature and provides new experiences and fun views in listening to stories from Indonesian literature. Although many students are still not familiar with the "Sandiwara Sastra" program on the @budayakita 
podcast, they are interested after learning about the existence of the platform on Spotify. According to Meisyanti (2020), podcast content can certainly develop rapidly with the creativity of podcast makers or called podcasters. The content is adjusted to the characteristics of the podcast, namely based on the demand or request so that it fits the needs and desires of listeners. It also applies to the "Sandiwara Sastra" podcast, where students already feel interested and enthusiastic about using it. Students can also customize the selection of podcast content according to their needs and desires. It shows that this media can be an alternative in learning literature.

The daily life of students who cannot be separated from smartphones is also a factor in the opportunity for podcast consumption on the Spotify platform. As evidenced by the survey results, as many as $40 \%$ of students stated that the public's low interest in reading was due to the influence of digital media. In comparison, around $22.85 \%$ stated that the lack of facilities and interesting reading media was also a factor in low literacy interest. With a more attractive presentation accompanied by music, sound effects and visuals that dominate the field, the existence of literature will be increasingly developed and in demand. The results of the Jakpat survey conducted from October 5 to December 11 2020, on 2,368 respondents also showed that the number of podcast listeners listened to in Indonesia was dominated by young people. In detail, as many as $22.1 \%$ are respondents aged 15-19 years. The results of the Jakpat survey conducted from October 5 to December 11 2020, on 2,368 respondents also showed that the number of podcast listeners listened to in Indonesia was dominated by young people. In detail, as many as $22.1 \%$ are respondents aged $15-19$ years. Then, other podcast listeners aged 20-24 years reached $22.2 \%$. Furthermore, the listenership rate of these podcasts appears to decline with age. In the age range of 25-29 years, the number of podcast listeners is $19.9 \%$. Podcast listeners aged 30-34 are 15.7\%. Then, podcast listeners aged 35-39 years by $11.8 \%$. At the same time, podcast listeners in the age range of $40-44$ years are only $8.4 \%$. The dominating age level in the research data also shows that the younger generation plays a significant role with a relatively high percentage. On the other hand, Spotify as an application that provides literary drama podcasts also contributes to the effectiveness of podcasts to be listened to. Spotify is an audio-based platform or application that offers commercial streaming of music and podcasts. Spotify announced that podcast listeners on the platform more than doubled in 2020. Therefore, the medium chosen to express ideas and revive literary works in the form of podcasts is an innovative solution relevant to the current situation and conditions.

Podcasts have an influential role for students. According to Hew (2009) in Rachmawati et al. (2019), podcast media can influence students' interpretation. In literary works, the influence of cognition is needed to understand and appreciate the message the creator wants to convey. With the advantages of podcasts in students' cognitive impact, students can better understand the meaning and learn literary works through this audio-based media. Another effective side of podcasts is that students feel more involved when listening to podcasts than other media to increase understanding of the topics discussed. The Reuters Institute study report (2020) in Nugroho and Irwansyah (2021) states that podcasts target young people because many young people feel that the topics discussed in podcasts are related to their personal lives. The study 
shows that podcasts can affect the emotional side of listeners from a young age, including college students. It is also related to the research of Chan and Lee (2005) in Rachmawati et al. (2019), which stated that podcasts could reduce student anxiety, especially during the pandemic, so that this media has a relatively high level of effectiveness for students. With the podcast "Sandiwara Sastra", it will be easier to introduce Indonesian literary works practically and flexibly to increase public interest, especially students, in the importance of the role and benefits of literature itself. Through podcasts, students can listen to literary works they want to know in a fun way. The different story content does not make students bored and enriches knowledge in various literary works. In this case, podcasts are useful as a medium of information and entertainment and literary education media that can be used whenever and wherever listeners are. Obviously, this will increase students' motivation and interest in Indonesian literary works so that the existence of literary works is maintained and follows the times, namely by using digital media as an intermediary.

\section{CONCLUSION}

Based on this research, it was found that podcast media can be an alternative for literary development because the preference for digital media is getting higher every day. The podcast that researchers use as an alternative medium for developing literary works is podcast "Sandiwara Sastra" which is a transfer of literature to audio form. In this case, this podcast is considered influential in developing Indonesian literary works by influencing interpretation in capturing meaning and studying literary works practically and flexibly. As a result, this form of introduction to literary works can be a medium to interpret the importance of the role and benefits of literature itself increase public interest especially college students.

Recommendation from this research is conveyed in increasing students' understanding and interest in literature through digital podcast media. In this case, the literature will not be swallowed by the modernization era, and its distribution can follow the current dynamic developments. Therefore, presenting this alternative media is expected to strengthen the existence of literature for college students.

The limitation in this research lies in the variation of the respondents. The researchers realize that there are still many shortcomings and weaknesses in this research. One of them is the limited number of respondents who only cover college students, which needs to be increased to achieve greater generalization. 


\section{REFERENCES}

Adzani D.M. \& Jumino U. (2020). Pemanfaatan Podcast dan Instagram oleh Komunitas Literatif sebagai Media Penyebaran Informasi Bidang Perpustakaan. ANUVA: Jurnal Kajian Budaya,Perpustakaan dan Informasi. 4(3), 27-42. https://doi.org/10.14710/anuva.4.3.327-342

Anggriani Y. (2020). Pemanfaatan Gadget dalam Meningkatkan Minat Baca Anak di Keluarga. Jurnal Perpustakaan Universitas Airlangga. 29(2), 138-147. http://dx.doi.org/10.20473/jpua.v10i2.2020.138-147

Aufadina K. \& Irfansyah M. (2021). Modernisasi, Layar Monitor, dan Perubahan Budaya. LAKON: Jurnal Kajian Sastra dan Budaya. 10(1), 1-10. https://doi.org/10.20473/lakon.v10i1.27030

Aufar A.F \& Raharjo S.T. (2020). Kegiatan Relaksasi sebagai Coping Stress di Masa Pandemi Covid-19. Jurnal Kolaborasi Resolusi Konflik. 2(2), 157-163. https://doi.org/10.24198/jkrk.v2i2.29126

Danuri M. (2019). Perkembangan dan Transformasi Teknologi Digital. INFOKAM: Jurnal Ilmiah Informasi Komputer, Akuntansi dan Manajemen. 15(2), 116-123. https://doi.org/10.53845/infokam.v15i2.178

Ekawati M. \& Baihaqi I. (2020). Peran bahasa di masa pandemi covid-19 sebagai media terapi kognitif. Edisi Kesatu. Yogyakarta: Anom Pustaka.

Fadillah I.N \& Dini K. (2021). Digital Storytelling sebagai Strategi Baru Meningkatkan Minat Literasi Generasi Muda. Journal of Education Science. 7(2), 83-98. https://doi.org/10.3314/jes.v7i2.1566

Fadli M.R. (2021). Memahami Desain Metode Penelitian Kualitatif. HUMANIKA: Kajian Ilmiah Mata Kuliah Umum. 21(1), 33-54. https://doi.org/10.21831/hum.v21i1.38075

Faradinna N. (2020). Peran podcast dalam membangun knowledge society. Laporan Tugas Akhir Universitas

Pertamina. https://library.universitaspertamina.ac.id//xmlui/handle/123456789/1124

Fauziah (2021). Sandiwara Sastra, Angkat Literasi Karya Sastra Indonesia. Retrieved November 27, 2021. Available from: https://kebudayaan.kemdikbud.go.id/sandiwarasastra-angkat-literasi-karya-sastra-indonesia/

Fitria L., Neviyarni, Netrawati \& Karneli Y. (2020). Cognitive Behavior Therapy Counseling Untuk Mengatasi Anxiety Dalam Masa Pandemi Covid-19. Jurnal Pendidikan dan Konseling. 10(1), 23-29. http://dx.doi.org/10.30829/al-irsyad.v10i1.7651 
Fitriyani, S. S., \& Sumiyadi (2021). Puisi Bergaya Haiku Dalam Cyber Sastra Indonesia Di Era Milenial (2018-2019). Jurnal Bahtera Sastra Indonesia, 3(1), 11-22. https://ejournal.upi.edu/index.php/BS_Antologi_Ind/article/view/40952/0

Hardani, Auliya N.H, Andriani H, Fardani R.A, Ustiawaty J., Utami E.F, et al. (2020). Metode penelitian kualitatif \& kuantitatif. Edisi Kesatu. Yogyakarta: CV. Pustaka Ilmu Group Yogyakarta.

Helaluddin \& Wijaya H. (2019). Analisis data kualitatif: sebuah tinjauan teori dan praktik. Edisi Kesatu. Makassar: Sekolah Tinggi Theologia Jeffray.

Hikmawati V., Sasmika M, \& Hartati D. (2021). Transformasi Cerpen Mencari Herman Karya Dewi Lestari ke dalam Bentuk Audio Sandiwara Sastra Mencari Herman. Jurnal Literasi. 5(2), 268-278. http://dx.doi.org/10.25157/literasi.v5i2.5850

Hutabarat P.M. (2020).Pengembangan Podcast sebagai Media Suplemen Pembelajaran Berbasis Digital pada Perguruan Tinggi. Jurnal Sosial Humaniora Terapan. 2(2), $107-$ 116. https://doi.org/10.7454/jsht.v2i2.85

Jailani M. S. (2020).Membangun Kepercayaan Data Dalam Penelitian Kualitatif. Primary Education Journal. 4(2),

https://pej.ftk.uinjambi.ac.id/index.php/PEJ/article/view/72

Laila D. (2020). Inovasi perangkat pembelajaran menggunakan aplikasi podcast. Prosiding Seminar Nasional Pembelajaran Bahasa dan Sastra Indonesia (pp.7-12). Universitas Negeri Medan.

Manuaba I. B. P (2019). Komunitas Sastra, Produksi Karya dan Pembangunan Karakter. Mozaik Humaniora. 19(1), 37-47. http://dx.doi.org/10.20473/mozaik.v19i1.10563

Mayangsari D. \& Tiara D. R. (2019). Podcast sebagai Media Pembelajaran di Era Milenial. Jurnal Golden Age Universitas Hamzanwadi. 3(2), 126-135. https://doi.org/10.29408/goldenage.v3i02.1720

Meisyanti, W. H. K. (2020). Platform Digital Siaran Suara Berbasis On Demand (Studi Deskriptif Podcast Di Indonesia). Jurnal Komunikasi Dan Media. 4(2), 191-207. https://doi.org/10.33884/commed.v4i2.1547

Mekarisce. A.A. (2020).Teknik Pemeriksaan Keabsahan Data pada Penelitian Kualitatif di Bidang Kesehatan Masyarakat. Jurnal Ilmu Kesehatan Masyarakat. 12(3), 145-51. https://doi.org/10.52022/jikm.v12i3.102

Mulyani R. (2021). Eksplorasi Terhadap Kemungkinan Desain Podcast Pendidikan Tinggi di Indonesia. AKSARA: Jurnal Ilmu Pendidikan Nonformal. 7(2), 381-394. http://dx.doi.org/10.37905/aksara.7.2.381-394.2021 
Mushlihah N. Q. (2020).Proses Konstruksi Identitas Pembaca Karya Sastra Jawa di Kalangan Anak Muda Urban. Palimpsest : Journal of Information and Library Sciences. 11 (2), 106-124. http://dx.doi.org/10.20473/pjil.v11i2.24195

Nugroho, I. \& Irwansyah. (2021). Konvergensi Konten Audio di Media Online (Studi Kasus $\begin{array}{lllr}\text { Podcast Detik.com). Jurnal Komunikasi. } & \text { 15(1), }\end{array}$ https://doi.org/10.21107/ilkom.v15i1.9753

Nurhidayah S. \& Setiawan R. (2019). Lanskap Siber Sastra: Postmodernisme, Sastra Populer, dan Interaktivitas. POETIKA: Jurnal Ilmu Sastra. 7(2), 136-147. https://doi.org/10.22146/poetika.v7i2.50779

Nursanjaya. (2021). Memahami Prosedur Penelitian Kualitatif: Panduan Praktis Untuk Memudahkan Mahasiswa. NEGOTIUM: Jurnal Ilmu Administrasi Bisnis. 4(1),126-141. https://ojs.unimal.ac.id/na/article/view/4925

Panjaitan J. E. R (2021). Sosio-demografi dan Kepuasan Pengguna Podcast di Indonesia. Jurnal Spektrum Komunikasi. 9(1), 13-23. https://doi.org/10.37826/spektrum.v9i1.155

Rachmawati, F., Muhajarah, K., \& Kamaliah, N. (2019). Mengukur Efektivitas Podcast sebagai Media Perkuliahan Inovatif pada Mahasiswa. JUSTEK: Jurnal Sains dan Teknologi. 2(1), 38-44. https://doi.org/10.31764/justek.v2i1.3750

Ridwan A, Firmansyah M.B \& Rosyidah I. (2021). Pemanfaatan media sosial sebagai media pembelajaran sastra di era digital. Prosiding Transformasi Pembelajaran Nasional 2021 (pp. 381-394). Universitas PGRI Wiranegara.

Saepuloh M.F., Nurwahidah L.S. \& Kartini A. (2021). Media Pembelajaran Podcast untuk Meningkatkan Keterampilan Menulis Puisi.Caraka: Jurnal Pendidikan Bahasa dan Sastra Indonesia serta Bahasa Daerah. 10(2), 107-116. https://doi.org/10.31980/caraka.v10i2.1401

Sidiq U. \& Choiri M.M. (2019) Metode penelitian kualitatif di bidang pendidikan. Edisi Kesatu. Ponorogo: CV. Nata Karya.

Statista Research. (2020). Department. U.S. Consumers Who Listen To Audio Podcasts 2020. Retrieved November 27, 2021 Available from: https://www.statista.com/statistics/188955/percentage-of-usadults-who-listen-toaudiopodcasts-since-2006/

Sucin S., Savitri L \& Utami S. (2020). Konvergensi Media Baru dalam Penyampaian Pesan Melalui Podcast. Koneksi. 4(2), 235-242. http://dx.doi.org/10.24912/kn.v4i2.8113

Sulaiman Z. (2020). Peluang, Tantangan, dan Ancaman Sastra Cyber di Era Masyarakat Modern. Caraka: Jurnal Pendidikan Bahasa dan Sastra Indonesia serta Bahasa Daerah, 9(3), 164-169. https://doi.org/10.31980/caraka.v9i3.916 
Sundari G. \& Purba V. (2020). Strategi Komunikasi Podcaster Awal Minggu Dalam Membuat Konten Podcast Di Spotify. Diakom: Jurnal Media dan Komunikasi. 3(2), 148-156. https://doi.org/10.17933/diakom.v3i2.82

Surahman E, Satrio A, Sofyan H. (2020). Kajian Teori Dalam Penelitian. Jurnal Kajian Teknologi Pendidikan. 3(1), 49-58. http://dx.doi.org/10.17977/um038v3i12019p049

Wahyuni D. (2020) Meningkatkan Pembelajaran Sastra melalui Perkembangan Era Digital. $\begin{array}{lllll}\text { Jurnal Bahasa, Sastra dan } & \text { Budaya. }\end{array}$ https://doi.org/10.24114/kultura.v1i1.18268

Widiastuti D.A. (2020). Pendengar Podcast Spotify Meningkat Dua Kali Lipat. Retrieved November 27, 2021. Available from: https://www.tek.id/tek/pendengar-podcastspotifymeningkat-dua-kali-lipat-b1ZQ69i5R

Yusanta F.B \& Wati R. (2020) Eksistensi Sastra Cyber: Webtoon dan Wattpad Menjadi Sastra Populer dan Lahan Publikasi Bagi Pengarang. Literasi: Jurnal Penelitian Bahasa dan Sastra Indonesia. 4(1),1-7. http://dx.doi.org/10.25157/literasi.v4i1.3080

Yusanto Y. (2019). Ragam Pendekatan Penelitian Kualitatif. Journal of Scientific Communication. 1(1), 1-13.http://dx.doi.org/10.31506/jsc.v1i1.7764

Zellatifanny C.M. (2020). Tren Diseminasi Konten Audio on Demand melalui Podcast: Sebuah Peluang dan Tantangan di Indonesia. Jurnal Pekommas. 5(2), 117-132. http://dx.doi.org/10.30818/jpkm.2020.2050202

Zulfa A. N. (2021). Teori Ekokritik Sastra: Kajian terhadap Kemunculan Pendekatan Ekologi Sastra yang dipelopori oleh Cheryll Glotfelty. LAKON: Jurnal Kajian Sastra dan Budaya 2021. 10(1), 59-63. https://doi.org/10.20473/lakon.v10i1.20198 